\title{
Analysis of the Helix Number of Hard Twisted Yarn in Cotton Crepe Fabrics
}

\author{
NiSHIKAWA Shigekazu ${ }^{\mathrm{a}, *}$, TAKATERA Masayuki ${ }^{\mathrm{b}}$, MIYAKE Hajime ${ }^{\mathrm{c}}$, SHINOHARA Akira ${ }^{\mathrm{d}}$ \\ ${ }^{a}$ Miyagi University of Education, Sendai, Miyagi 980-0845, Japan \\ b Shinshu University, Ueda, Nagano 386-8567, Japan \\ ${ }^{\mathrm{c}}$ North Eastern Industrial Research Center of Shiga Prefecture, Nagahama, Shiga 526-0024, Japan \\ ${ }^{\mathrm{d}}$ Shinshu Junior College, Saku, Nagano 385-0022, Japan
}

Received 21 June 2006; accepted for publication 28 June 2007

\begin{abstract}
In this paper, the helix number of hard twisted yarn was analyzed by both theory and experiment. The shape of hard twisted yarn was supposed as the helix and the helix number was examined from the dynamic balance of moment.

The results obtained are as follows:

1) Bending rigidity and twisting moment are strongly concerned in the deformation of hard twisted yarn.

2) The smaller the bending rigidity of hard twisted yarns, the larger the helix numbers of hard twisted yarn.

3) By increasing the twisted moment, the helix number of hard twisted yarns increases.
\end{abstract}

Key Words: Helix number, Hard twisted yarn, Twisting moment, Crepe fabric

\author{
綿クレープ織物中の強撚糸が作るらせん数の解析 \\ 西川重和 ${ }^{\mathrm{a},{ }^{*}}$ ，高寺政行 ${ }^{\mathrm{b}}$ ，三宅 肇 ${ }^{\mathrm{c}}$, 篠原 昭 ${ }^{\mathrm{d}}$ \\ ${ }^{a}$ 宮城教育大学， ${ }^{b}$ 信州大学, ${ }^{c}$ 滋賀県東北部工業技術センター, ${ }^{d}$ 信州短期大学
}

\section{1. 緒 言}

よこ糸に強い撚りを挿入した織物は強撚糸織物と呼ばれ, 素材に綿を用いた織物をクレープ織物と呼んでいる。この織 物は，布表面にしぼと呼ばれる凹凸の形状を有しているのが 特徴で，この凹凸形状のしぼがシャリ感の風合いを有するた めに，夏用の肌着やパジャマに主に使用されている.

クレープ織物の製造は，経験と試行錯誤により行われてい るため，現在では経験をもつ織物設計者の減少と高齢化が問 題となっている. また, 生産方式においても少品種大量であ り，NIEsからの競合にあいやすい製品でもある．将来のク レープ織物の存続あるいは需要拡大のためには, 若手の人材 育成やアウター分野へのさらなる進出等を図っていく必要が ある。そのためには，布設計段階においてしぼ形状を予測す ることが重要である.

クレープ織物のしぼ設計に関する最近の研究では, 山本
ら[1]はポリエステル楊柳織物のしぼ形態とその形成機構と して, Hearlら[2]の円筒状モデルを応用して，これにスナー ル形成する際に織物をせん断変形させるに要する仕事を考慮 したモデル提案を行い，しぼの高さと周期を求めることを試 みている。また，小森ら[3]は，山本ら[1]の文献中の式のせ ん断ひずみエネルギーの式に修正を加え, さらに新しい考え として糸が残留トルクを有する場合に，糸が直線で幾何学的 な据率が0であっても0でない据りエネルギーを持つ（よこ 糸に残留トルクに相当する過剩なよりが与えられている状 態）として臨界残留よりを加えたモデルの提案を行い，しぼ の形成機構について報告している.

また，石倉ら[4-6]は微小変形を仮定し，ねじりと曲げを 伴う棒の安定問題を応用し, 軸力のある場合の両端球節境界 条件での座屈条件を導き, 軸力がない場合の座屈形状が helix であることを示し，絹と綿の強撚糸織物についてのらせん数 について理論と実験の両方から詳細に解析を行っている.

* 連絡先 : 宮城教育大学教育学部 980-0845 仙台市青葉区荒巻字青葉 149, E-mail: nishika@ staff.miyakyo-u.ac.jp 
本報では, 綿クレープ中の強撚糸の3 次元変形をらせん変 形と仮定してhelix の力学的釣り合のモデルから, らせん数 を求める予測式を算出した. らせん数の予測式には, しぼ発 生時である熱湯中でのよこ糸の解撚トルクの数值が必要とな る. しかし, 熱湯中での糸の解撚トルクの測定は非常に困難 であり, 従来は加撚時のトルクで置き換えているのが現状で ある.そこで, 我々は実験から加撚トルクと解撚トルクの両 方を測定し，トルクの違いがらせん数におよぼす影響につい て検討を行った。

また，石倉ら[6]は綿クレープ織物のよこ糸に双糸からな る強撚系を用いて， S 撚と Z撚を何本か交互に配列し，その 時のよこ糸の撚数がらせん数に及ぼす影響について解析を 行っている. しかし, 一般的な綿クレープ織物とは, Z撚の 単糸の原糸をさらにZ方向に追撚した強撚糸のみを配列した 織物であり，本来の綿クレープの糸構造と異なっている. そ のため, 一般的なクレープ設計するための基本的なデータが 得られていない. そこで, 我々はよこ糸にZ撚の単糸からな る強撚糸のみを配列した織物を試作し, その時のよこ系の撚 数と密度の変化がらせん数に与える影響について検討した.

\section{2. 記 号}

本報で用いる主な記号を以下に示す。

空間固定座標軸

$x: x$ 軸
$y: y$ 軸
$z: z$ 軸

材料固定座標軸

$w$ 軸: 接線方向 (接線)

$u$ 軸：側面方向（主法線）

$v$ 軸：上面方向（従法線）

オイラー角

$\theta: z$ 軸と $w$ 軸

$\phi: z x$ 面と $z w$ 面

$\Psi: w u$ 面と $w z$ 面のなす角

$\alpha$ : らせんの傾斜角, $\alpha=(\pi / 2)-\theta$

$s:$ 弧長

$R:$ 円筒の半径

$p, q, r: u, v$ 軸曲率および $w$ 軸㧖率

$L, l:$ 製布後の織物の長さと精練後の織物の長さ

\section{3. 理 論}

\section{1 モデル化}

クレープ織物中の強撚糸がらせん形状であることはよく知 られている[1-6].

Fig. 1 は精練工程後の綿クレープ織物から強撚糸（よこ糸） を取り外した時の糸の形態を示す. Fig. 1 から強撚系は, ら せん形態をとっていると考えられる．精練工程後のよこ糸の 強撚糸のモデルとして Fig. 2に示すようならせん形態をとる と仮定して解析する.

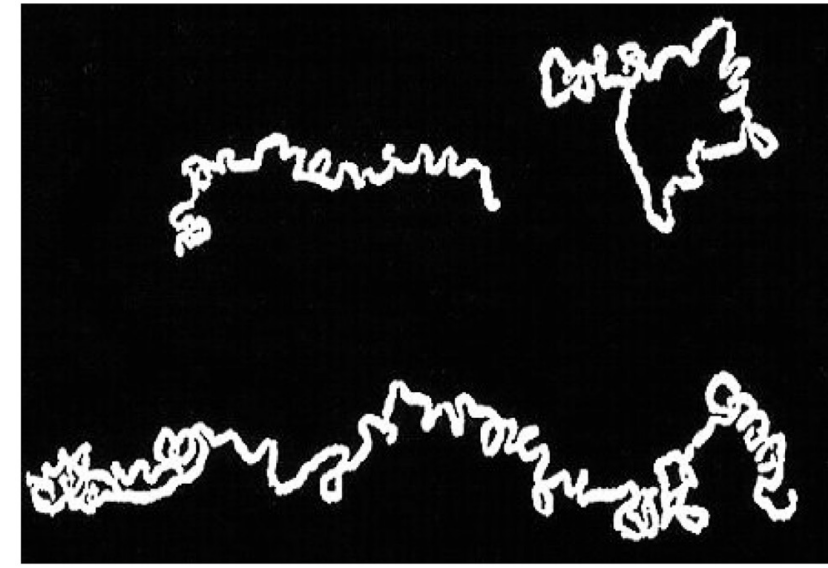

Fig. 1 A crepe yarns form.
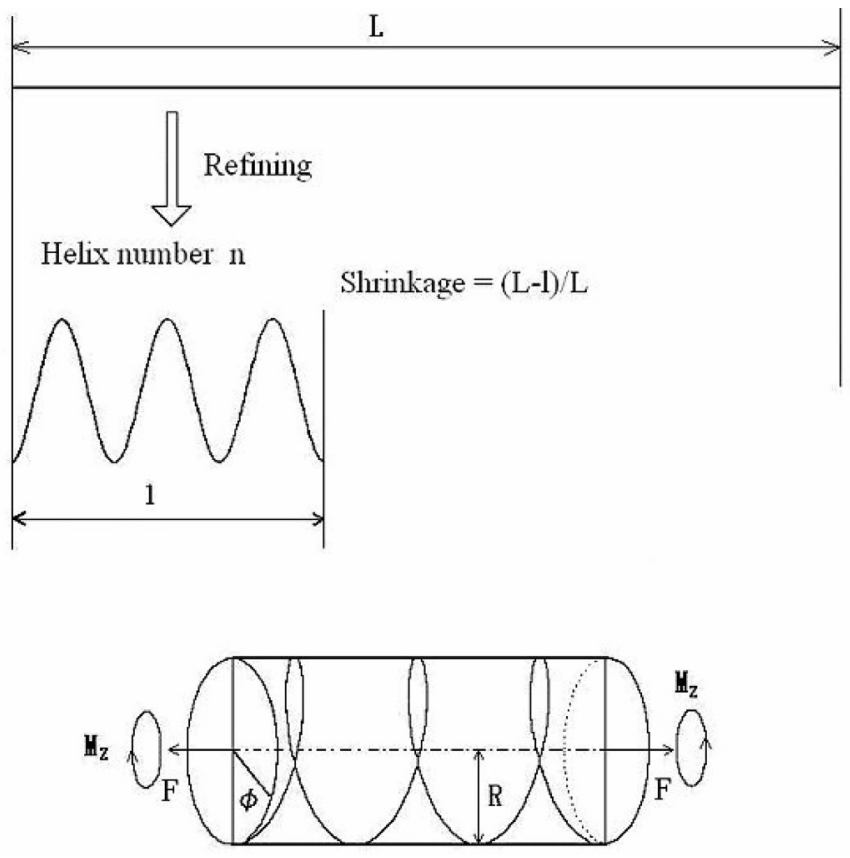

Fig. 2 Model of hard twisted yarns.

\section{2 基礎方程式の構築}

初期状態でまっすぐな棒がhelixに変形する際の釣り合い の方程式は解析的に導くことができ[7], らせん形状はFig. 3 に示すように, 両端における $z$ 軸方向の力 $\mathrm{F}$ と $z$ 軸回りのト ルク $M_{z}$ により保持されるものとする.

Helixの場合

$\theta:$ 定数 $\frac{d \theta}{d s}=0$

$\phi:$ 接線の円筒断面に投影した角

$s \cos \alpha=\phi R, \quad \frac{d \phi}{d s}=\frac{\cos \alpha}{R}$

曲率とオイラー角の関係より，

$p=\frac{-\cos ^{2} \alpha \cos \phi}{R}, q=\frac{\cos ^{2} \alpha \sin \phi}{R}, r=\frac{\cos \alpha \cos \alpha}{R}+\frac{d \phi}{d s}(4,5,6)$ 
$A, B$ を曲げ剛性, $C$ をねじれ剛性, 外力の $u, v$ 成分を $F_{u}, F_{v}$ とすると，

$$
\begin{aligned}
& A p^{\prime}-(B-C) q r=F_{v} \\
& B q^{\prime}-(C-A) p r=-F_{u} \\
& C r^{\prime}-(A-B) q p=0
\end{aligned}
$$

式(4)および(5)を微分すると，

$$
p^{\prime}=\frac{\cos ^{2} \alpha \sin \phi}{R} \phi^{\prime}, q^{\prime}=\frac{\cos ^{2} \alpha \cos \phi}{R} \phi^{\prime}
$$

式(6)より,

$$
\phi^{\prime}=\frac{d \phi}{d s}=r-\frac{\cos \alpha \cos \alpha}{R}
$$

糸断面の対称性より, $B=A$ である, 式(7，8)に式(4), (5), (10) (11), (12)を代入すると，

$$
\begin{aligned}
& F_{v}=\sin \phi\left(\frac{C r \cos ^{2} \alpha}{R}-\frac{B \cos ^{3} \alpha \sin \alpha}{R^{2}}\right) \\
& -F_{u}=\cos \phi\left(\frac{C r \cos ^{2} \alpha}{R}-\frac{B \cos ^{3} \alpha \sin \alpha}{R^{2}}\right)
\end{aligned}
$$

外力 $F$ の成分 $x, y, z\left(0,0, F_{z}\right)$ を $u, v, w$ 成分で表すと,

$$
F=\left(F_{u}, F_{v}, F_{w}\right)=F_{z}(-\sin \theta \cos \phi, \sin \theta \sin \phi, \cos \theta)
$$

式(14)より，

$$
\begin{aligned}
& \cos \phi\left(\frac{C r \cos ^{2} \alpha}{R}-\frac{B \cos ^{3} \alpha \sin \alpha}{R^{2}}\right)=F_{z} \cos \alpha \cos \phi \\
& \therefore \quad F_{z}=\frac{\cos \alpha}{R}\left(C r-\frac{B \cos \alpha \sin \alpha}{R}\right)
\end{aligned}
$$

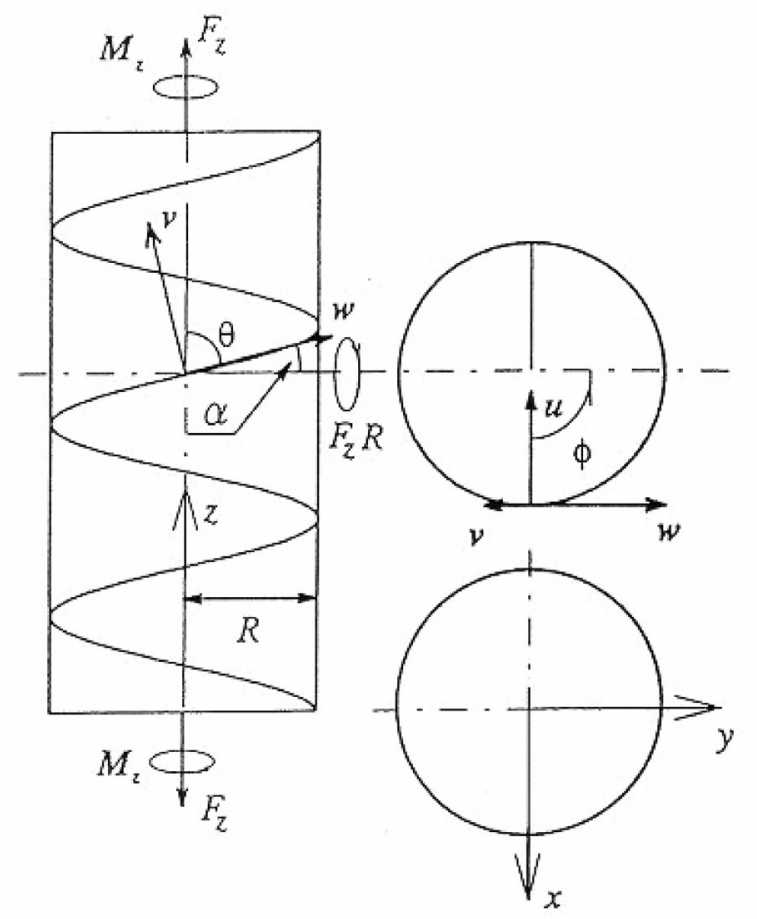

Fig. 3 Geometry of a cylindrical surface.

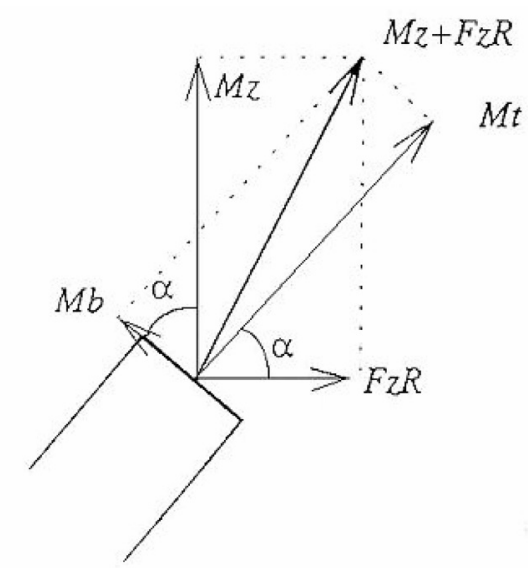

Fig. 4 Moment which acts on the helix.

終端モーメントの軸はhelixの中心線の終端において, 円 筒の接線平面 (tangent plane) 内にある.この点におけるその モーメントの helix の従線方向成分 $M_{b}$ は幾何曲率 $\boldsymbol{\kappa}=\cos ^{2} \alpha / R$ より,

$$
M_{b}=\frac{B \cos ^{2} \alpha}{R}
$$

helix の接線方向成分 $M_{t}: M_{t}=C r$

このモーメントはFig. 4 に示すように $P R$ と $M_{z}$ の合モーメン トの接線成分で与えられる。

$C r の M_{z}$ 軸方向成分 : $C r \sin \alpha$

従法線ベクトル $b=\sin \alpha \sin \phi i-\sin \alpha \cos \phi j+\cos \alpha k$ より，

$M_{b}$ の $M_{z}$ 軸方向成分 : $\frac{B \cos ^{3} \alpha}{R}$

よってモーメントは, $M_{z}$

$$
M_{z}=C r \sin \alpha+\frac{B \cos ^{3} \alpha}{R}
$$

初期真直な側面が常に円柱面に接するとき， $u$ 軸は常に $x y$ 平 面内にあり，

$$
\phi=\pi / 2, \frac{d \phi}{d s}=0
$$

ねじれ率 $: r=\frac{\sin \alpha \cos \alpha}{R}$

曲率: $p=0, q=\frac{\cos ^{2} \alpha}{R}$

式(21)を式(17),(19)に代入すると,

$$
\begin{aligned}
& F_{z}=\frac{\left(\cos ^{2} \alpha \sin \alpha\right)(C-B)}{R^{2}} \\
& M_{z}=\frac{\left(C \sin ^{2} \alpha+B \cos ^{2} \alpha\right) \cos \alpha}{R}
\end{aligned}
$$

モーメントだけで力が作用しない場合は,

$$
\begin{aligned}
& M_{z}=\frac{B \cos \alpha}{R} \quad(\text { 軸は helix の軸に平行) } \\
& r=\frac{B \sin \alpha \cos \alpha}{C R}
\end{aligned}
$$




$$
\therefore \text { 軸モーメント } M_{t}=C r \frac{B \sin \alpha \cos \alpha}{R}
$$

らせんの幾何学的関係より, 単位長さ当たりのらせん数 $n / L$ ( $n$ はらせん数 $)$

$$
\frac{n}{L}=\frac{M_{t}}{E I} \frac{1}{2 \pi \sin \alpha}
$$

\section{3 計算例}

Fig. 5 は $M_{t} / E I$ を変化させた時のらせん数とらせん角度の関 係を示す。らせん数はらせん角度が大きくなるに従いらせん 数は減少する. $M_{t} / E I$ が大きくなるとらせん数は増加する. 仮に $M_{t}$ を一定と仮定した場合, 糸の曲げ剛性 $E I$ が小さくな るほどらせん数は増加する。これは糸の直径が細くなるほど らせん数が増加することを意味する. また, 糸の曲げ剛性 $E I$ が一定の場合, 糸のモーメント $M_{t}$ が大きくなるに従いらせ ん数は増加する.これは, 糸の撚数が増加するに従いらせん 数も増加することを意味する.

この結果から綿クレープ織物の場合においては，細かいし ぼ形状を得るためには強撚糸の糸の太さが細いものを使用 し，また限界に近い撚数を与える必要がある。

同様に，たて糸においても糸の太さが細い（曲げ剛性の小 さい) 糸を使用することにより, よこ糸 (強撚糸) が精練後 においてらせん形状をとる時の抵抗力が小さくなり，しぼが 得やすくなる。この事については, よこ糸の撚数, たて・よ こ系の番手を変えた織物を試作し, 実験により[8]確認を 行っている. 本モデルを用いて定性的にしぼ形状の説明を行 うことが可能である。

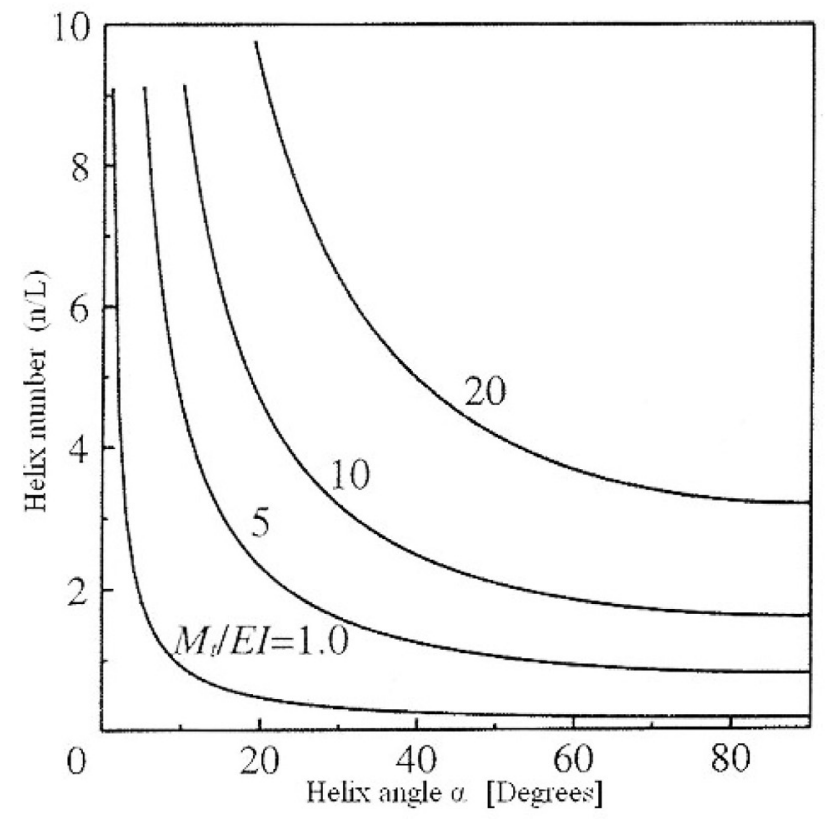

Fig. 5 Relation between helix number and helix angle.

\section{4. 実 験}

\section{1 試料}

試料の原糸には，一般的に綿クレープ織物に用いられてい る綿の単糸を用いた。綿原糸の詳細をTable 1 に示す。なお， 表中の紡績撚数は敷島紡績 (株) 製自動検撚機による, 試料 長 $25 \mathrm{~cm}$ ，試験回数 10 での実測值の平均である.

撚数と解撚トルクの関係を調べるために, 紡績糸撚と同方 向の Z（左）方向にリング撚糸機（共立機械製）を用い約 100 回/mづつ撚数の異なる追撚を行い，総撚数を実測した. 得られた試料の原撚数, 追撚数, 総撚数を Table 2 に示す.

また，解撚トルクの測定には，前もって撚糸した糸の撚止 めを行う必要があり，真空糸蒸熱セット機（昭和工業製）を 用いて, 湿式状態でセット温度 $105{ }^{\circ} \mathrm{C}$, セット時間 20 分で糸 の撚止めを行った。これは実際に綿クレープ織物製造時に用 いられている標準の条件である.また，加撚トルクの測定に も Table 1の原糸を用いた。

\section{2 実 験}

解撚トルクおよび加撚トルクの測定には，カトーテック製 KES-YN-1 を使用した. Fig. 6に本装置の構成を示す。

本実験においては熱湯中での糸の解撚トルク測定のため, Fig. 7 に示すように，左右にガイドのあるガラス管の製作を 行い, 実験を行った。

Table 1 Details of cotton raw thread.

\begin{tabular}{|c|c|c|c|c|c|}
\hline $\begin{array}{c}\text { Yarn Count } \\
\mathrm{s}(\mathrm{tex})\end{array}$ & Raw cotton & Carding & Spinning & $\begin{array}{c}\text { Twist } \\
\text { direction }\end{array}$ & $\begin{array}{c}\text { Twist in spinning } \\
\text { (turns/m) }\end{array}$ \\
\hline \hline $40(14.8)$ & Pakistan & Card & Ring & $\mathrm{Z}$ & 1000 \\
\hline
\end{tabular}

Table 2 Cotton yarn samples.

\begin{tabular}{|c|c|c|c|c|c|}
\hline $\begin{array}{c}\text { Yarn } \\
\text { No. }\end{array}$ & $\begin{array}{c}\text { Yarn count } \\
\mathrm{s}(\mathrm{tex})\end{array}$ & $\begin{array}{c}\text { Original Twist } \\
\text { (turns } / \mathrm{m})\end{array}$ & $\begin{array}{c}\text { Additional Twist } \\
(\text { turns } / \mathrm{m})\end{array}$ & $\begin{array}{c}\text { Total Twist } \\
(\text { turns } / \mathrm{m})\end{array}$ & $\begin{array}{c}\text { untwisting Moment } \\
(\mu \mathrm{N} \cdot \mathrm{m})\end{array}$ \\
\hline \hline 1 & $40(14.8)$ & 1000 & 0 & 1000 & 0.06 \\
\hline 2 & $40(14.8)$ & 1000 & 113 & 1113 & 0.23 \\
\hline 3 & $40(14.8)$ & 1000 & 238 & 1238 & 0.31 \\
\hline 4 & $40(14.8)$ & 1000 & 346 & 1346 & 0.48 \\
\hline 5 & $40(14.8)$ & 1000 & 437 & 1437 & 0.52 \\
\hline 6 & $40(14.8)$ & 1000 & 602 & 1602 & 0.76 \\
\hline 7 & $40(14.8)$ & 1000 & 856 & 1856 & 0.93 \\
\hline
\end{tabular}

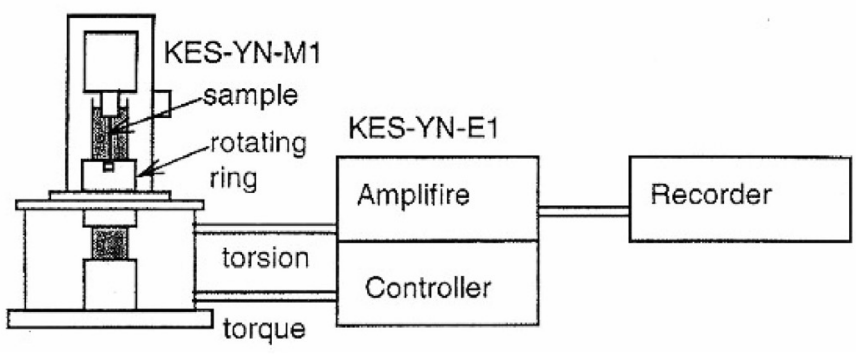

Fig. 6 Outlines of apparatus. 


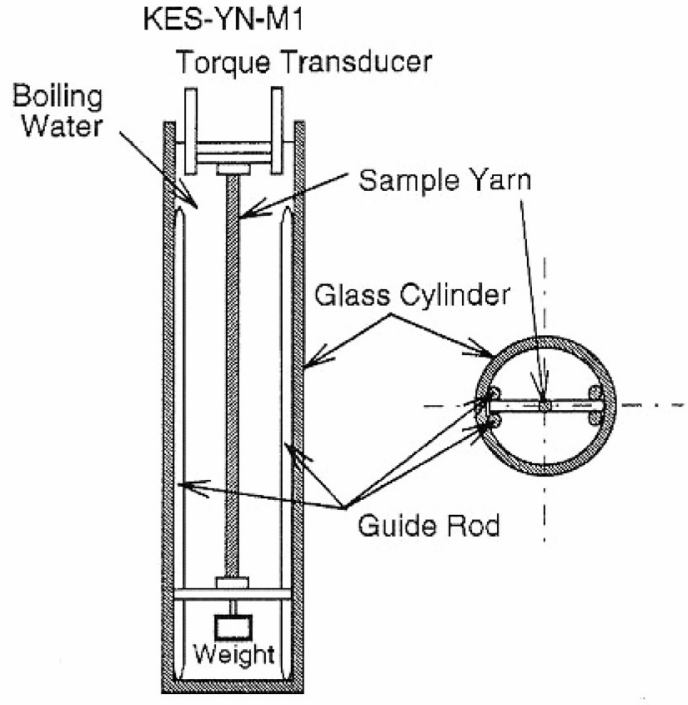

Fig. 7 Set up samples.

\section{3 試験方法}

\subsection{1 解撚トルクの測定}

解撚トルクは，撚止めセットが不十分で発生する乾式状態 での解撚トルクと, 熱湯中で発生する解撚トルクの和である. 実際のクレープ織物のシボ形状は，精錬工程中（熱湯中）で 発生することから，熱湯中で発生する解撚トルクが，クレー プ織物のしぼ形状に強い影響を与えていると考えられる。測 定においては, 試料を試験機にセットする際の不平衡の発生, おもりの影響, 乾式状態での解撚トルクの分離が困難なため, 熱湯中で発生する解撚トルクのみについて測定を行うものと し，撚糸後の糸に十分な撚止めセットを施し，試料セット時 の乾式状態でのトルクを0とした。試料を試験機のバーチャッ クにセットするために，試料にFig. 8に示す紙の支持部を貼 り付けた．長さ $100 \mathrm{~mm}$ の試料の下部バーチャックの中心の 下に $1.0 \mathrm{~g}$ の分銅を付け，静かに下部バーチャックを試験管 の溝に沿って下ろす. 分銅を付けるのはトルク発生時にスナー ルの発生を防ぐためである。上部バーチャックを上部チャッ ク受けに装着する。ここでトルクを 0 とし， $99{ }^{\circ} \mathrm{C}$ の水を静か に試験管に注ぐ。この時に発生するトルクを記録する。綿糸 は，糸の太さにばらつきがあるため，各試料 10 回の試験を 行いその平均值をデー夕とした，本測定では熱湯を入れ始め てから20秒後の值を採用した。
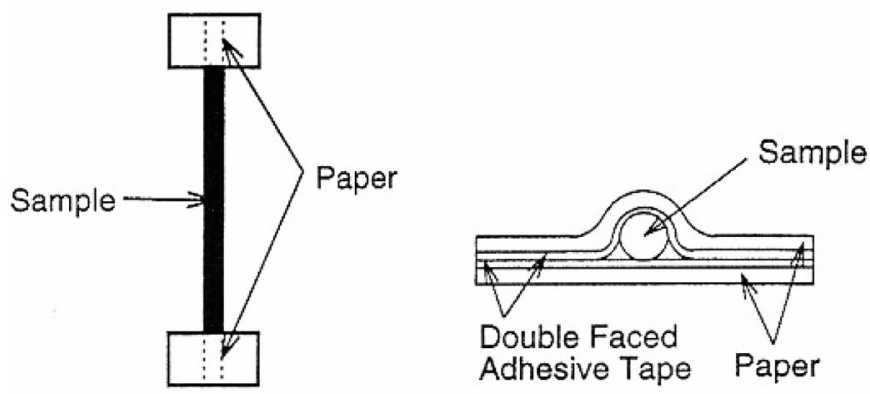

Fig. 8 Preparations to set samples to experimental device.
Table 3 Results of twisting torque test.

\begin{tabular}{|c|c|c|c|c|c|}
\hline $\begin{array}{c}\text { Yarn } \\
\text { No }\end{array}$ & $\begin{array}{c}\text { Yarn Count } \\
\mathrm{s}(\mathrm{tex})\end{array}$ & $\begin{array}{c}\text { Original Twist } \\
(\text { turns } / \mathrm{m})\end{array}$ & $\begin{array}{c}\text { Additional Twist } \\
(\text { turns } / \mathrm{m})\end{array}$ & $\begin{array}{c}\text { Total Twist } \\
(\text { turns } / \mathrm{m})\end{array}$ & $\begin{array}{c}\text { Twisting Moment } \\
(\mu \mathrm{N} \cdot \mathrm{m})\end{array}$ \\
\hline \hline 8 & $40(14.8)$ & 1000 & 113 & 1113 & 0.64 \\
\hline 9 & $40(14.8)$ & 1000 & 238 & 1238 & 1.35 \\
\hline 10 & $40(14.8)$ & 1000 & 1346 & 1346 & 2.42 \\
\hline 11 & $40(14.8)$ & 1000 & 437 & 1437 & 1.67 \\
\hline 12 & $40(14.8)$ & 1000 & 602 & 1602 & 3.12 \\
\hline
\end{tabular}

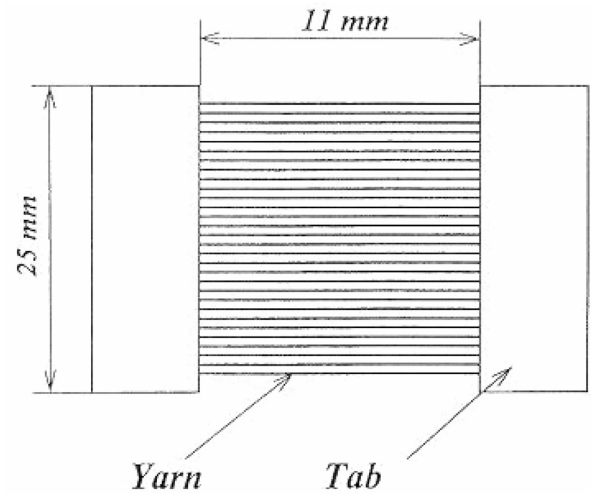

Fig. 9 Bending samples

\subsection{2 加撚トルクの測定}

長さ $10 \mathrm{~mm}$ の試料の下部バーチャックの中心の下に， $5.0 \mathrm{~g}$ の分銅を付ける。本来，解撚トルクと同じ $1.0 \mathrm{~g}$ の分銅を付 けるのが望ましいが，糸を加撚していくうちに二重撚が発生 するため，それを防ぐには重いおもりが必要となる。試料を 上下バーチャック受けに装着する。ここでトルクを0とし回 転リングを回転させ，設定した回転数（撚数）に達すると回 転を止め，この時発生したトルクを記録する。加撚 (MAX) とは回転停止後のトルクを表す。加撚 (Relax) とは回転停止 後，トルクが安定した時点でのトルクを表す．Table 3 に加 撚トルクの結果を示す。

\subsection{3 曲げ剛性の測定}

曲げ剛性の測定には，KES-F2 純曲げ試験機（カトーテッ ク製）を用い，得られた曲げモーメントー曲率曲線の往路 (変形が大きくなる方向に進むとき) で，曲率 1 ～ $2(1 / \mathrm{cm})$ に おける勾配より求めた。単系 1 本の曲げモーメントは微小な ため，Fig. 9に示すように試料 30 本を一つの面内で平行に並 べ両端を固定し測定を行った。その後 1 本当たりの曲げモー メントを算出した。

\subsection{4 らせん数の測定および $\sin \alpha の$ 算出}

40 番糸 (14.8 tex) をたて糸として密度 65 本 $/ 2.54 \mathrm{~cm} ，$ よこ 糸に 40 番系を用いて密度 $(45 \sim 65$ 本 $/ 2.54 \mathrm{~cm})$ と撚数 (追撚数 671〜1444回/m) を変化させた綿クレープを試織し，手もみ 精練後によこ糸を取り出して単位長さ当たりのらせん数を測 定し， $\sin \alpha を$ 算出した。 


\section{5. 試験結果および考察}

\section{1 解撚トルク, 加撚トルクおよび曲げ剛性の測 定結果}

Fig. 10 は綿糸の撚数と解撚トルクの関係を示す. 追撚数の 増加に伴い解撚トルクも増加する。 今回, 測定した範囲にお いての追撚数と解撚トルクは，ほぼ比例関係にある。 Fig. 11 は加撚トルクと追撚数の関係を示す. 追撚数の増加に伴い加 撚トルクも増加する。 Table 4 は標準状態 $\left(20 \pm 2{ }^{\circ} \mathrm{C}, 65 \pm 5 \%\right.$ RH) での綿糸の曲げ剛性の值を示す.

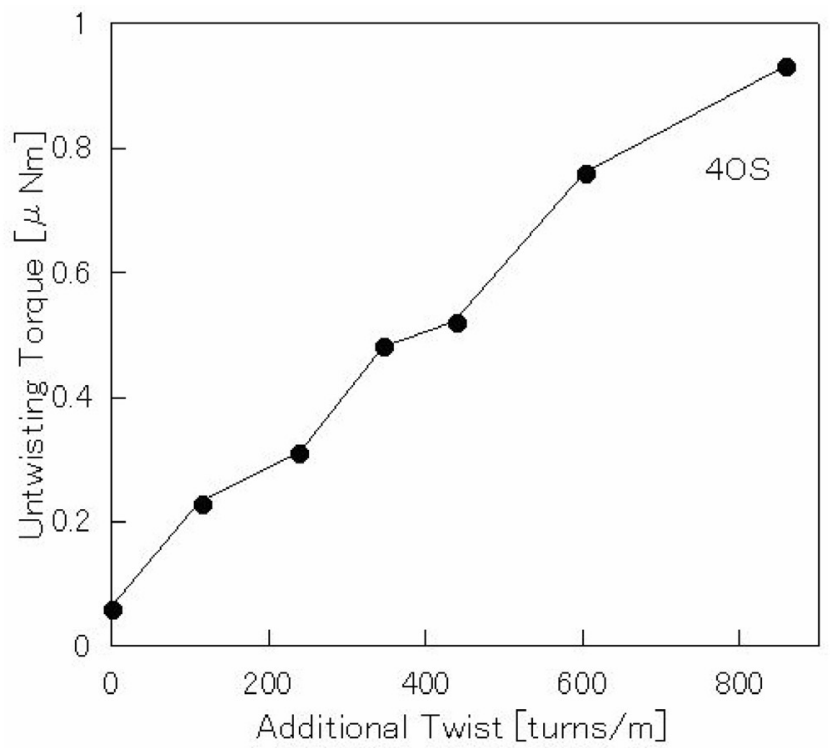

Fig. 10 Relationship between untwisting torque and additional twist number.

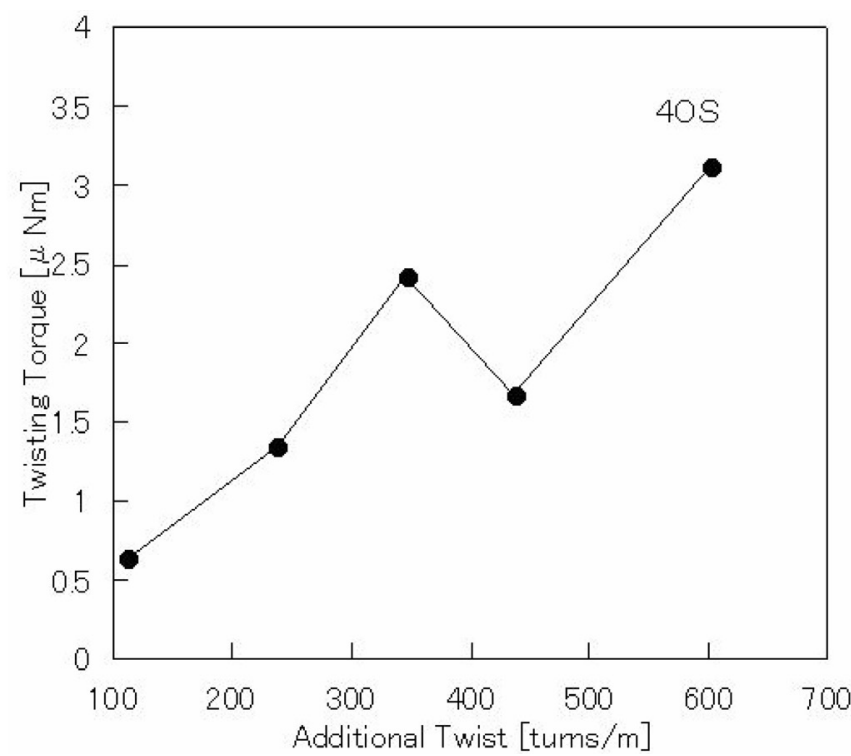

Fig. 11 Relationship between twisting torque and additional twist number.

Table 4 Bending rigidity of cotton yarns.

\begin{tabular}{|c|c|c|c|c|c|c|}
\hline $\begin{array}{c}\text { Yarn Count } \\
\mathrm{s}(\mathrm{tex})\end{array}$ & $\begin{array}{c}\text { Natural Twist } \\
\text { (turns } / \mathrm{m})\end{array}$ & $\begin{array}{c}\text { Additional Twist } \\
\text { (turns } / \mathrm{m})\end{array}$ & $\begin{array}{c}\text { Total Twist } \\
\text { (turns } / \mathrm{m})\end{array}$ & $\begin{array}{c}\text { Curvature } \\
(1 / \mathrm{cm}) \\
\mathrm{gfcm}\end{array}$ & $\begin{array}{c}\text { Curvatur } \\
\mathrm{e} \\
(2 / \mathrm{cm}) \\
\mathrm{gfcm}\end{array}$ & $\begin{array}{c}\text { Bending rigidity } \\
\mathrm{gfcm} \cdot \mathrm{cm}\end{array}$ \\
\hline \hline $40(14.8)$ & 980 & 1200 & 2180 & 0.0251 & 0.0378 & 0.0127 \\
\hline
\end{tabular}

\section{2 綿クレープのらせん数の予測}

本研究では，よこ糸にZ撚の強撚糸のみを用いた織物を試 作し，その時のよこ糸の撚数と密度の変化がクレープ織物の らせん数に与える影響について検討した。 Table 5 に試作し た綿クレープ織物の特性值を示す. Fig. 12 に試作したクレー プ織物中のよこ糸のらせん数n/1を示す. Fig. 12から，よこ 糸の追撚数の増加に伴いらせん数も増加している。これは, よこ糸撚数の増加は糸のモーメント（解撚トルク）の増加を 引き起こし，精錬後において織物の収縮率が大きくなるため であり，Fig. 5 と同様な結果である。 また，よこ糸密度の関 係でみると，たてよこ40番綿糸のクレープ織物では，よこ 糸密度が 55 本/ $2.54 \mathrm{~cm}$ が標準の製造条件である. Fig. 12 から, 本実験ではよこ糸密度が 55 本 $/ 2.54 \mathrm{~cm}$ のとにらせん数が最 大になる傾向を示した。このことから，クレープ産地での長 年の経験によって決定されたよこ糸密度は，らせん数が最大 になる密度で試行錯誤的に決定されたと推測される。また， その前後の密度で比較すると，45本より65本時の密度の方 がらせん数は全体的に少ない傾向を示した。原因として，よ こ糸密度の増加は, 織物全体での解撚トルクの増加に寄与す ると考えられるが，逆によこ糸がらせん形状を取るための空 間の減少につながり，よこ糸密度の増大がせん断変形の拘束 に強く作用したためと考えられる。

Table 6は綿クレープ織物のよこ糸のらせん数の予測值と 測定值を示す。追撚数 1186 回/ $/ \mathrm{m}$ の 40 番綿糸のよこ糸のク レープ中のらせん数 $\mathrm{n} / \mathrm{L}$ は，よこ糸密度 $45 \sim 60$ 本 $/ 2.54 \mathrm{~cm}$ の 範囲ではほぼ一定で，1.62〜 1.72 個/ cmであった。算出され た $\sin \alpha は 0.37 〜 0.53$ となる。同じ 40 番綿糸の解撚トルクは 追撚数 900 回 $/ \mathrm{m}$ までの範囲で直線的に増加することから予測 し, $0.0135 \mathrm{gf} \cdot \mathrm{cm}$ となり, 加撚時トルク (Max) は平均の解撚 時のトルクの約 4.4 倍であった。また標準状態の曲げ剛性は $0.0127 \mathrm{gf} \cdot \mathrm{cm}$ であった。 $M_{t}$ に加撚トルク，EIに曲げ剛性を代 入して求めたクレープ中の糸の $\sin \alpha に$ 対応する $\mathrm{n} / \mathrm{L} の$ 予測值 を見ると，予測值 $2 か ゙ 1.42 \sim 1.87 / \mathrm{cm}$ となり実験值に近い值 を示す. 予測值 2 とは加然 $(\mathrm{Max})$ の $M_{t}$ の值と標準状態での $E I$ を使用した值である。また，予測值 1 は解撚の $M_{t}$ の值と標準 状態での $E I$, 予測值 3 は加撚 (Relax) の值と標準状態での $E I$

Table 5 Characteristic of cotton crepe.

\begin{tabular}{|c|cc|c|c|c|c|}
\hline $\begin{array}{c}\text { Fabric } \\
\text { No }\end{array}$ & $\begin{array}{c}\text { Density } \\
\text { Ends Picks } \\
(1 / 2.54 \mathrm{~cm})\end{array}$ & $\begin{array}{c}\text { Yarn Count } \\
\text { Warp Weft } \\
\text { s(tex) }\end{array}$ & $\begin{array}{c}\text { Additional Twist } \\
\text { Weft } \\
(\text { turns } / \mathrm{m})\end{array}$ & $\begin{array}{c}\text { Shrinkage } \\
(L-l) / L \\
(\%)\end{array}$ & $\begin{array}{c}\text { Helix Number } \\
L=10 \mathrm{~cm}\end{array}$ \\
\hline \hline 1 & 65 & 65 & $40(14.8) 40(14.8)$ & 1444 & 55.0 & 18.3 \\
\hline 2 & 65 & 55 & $40(14.8) 40(14.8)$ & 1444 & 65.0 & 18.5 \\
\hline 3 & 65 & 45 & $40(14.8) 40(14.8)$ & 1444 & 62.3 & 18.0 \\
\hline 4 & 65 & 60 & $40(14.8) 40(14.8)$ & 1186 & 47.5 & 16.2 \\
\hline 5 & 65 & 55 & $40(14.8) 40(14.8)$ & 1186 & 63.2 & 16.8 \\
\hline 6 & 65 & 50 & $40(14.8) 40(14.8)$ & 1186 & 60.2 & 17.2 \\
\hline 7 & 65 & 45 & $40(14.8) 40(14.8)$ & 1186 & 59.8 & 16.3 \\
\hline 8 & 65 & 65 & $40(14.8) 40(14.8)$ & 1085 & 46.7 & 17.3 \\
\hline 9 & 65 & 55 & $40(14.8) 40(14.8)$ & 1085 & 57.5 & 17.7 \\
\hline 10 & 65 & 45 & $40(14.8) 40(14.8)$ & 1085 & 60.0 & 16.0 \\
\hline 11 & 65 & 65 & $40(14.8) 40(14.8)$ & 1009 & 54.2 & 17.2 \\
\hline 12 & 65 & 55 & $40(14.8) 40(14.8)$ & 1009 & 50.8 & 15.5 \\
\hline 13 & 65 & 45 & $40(14.8) 40(14.8)$ & 1009 & 30.8 & 14.0 \\
\hline 14 & 65 & 65 & $40(14.8) 40(14.8)$ & 676 & 18.3 & 5.8 \\
\hline 15 & 65 & 55 & $40(14.8) 40(14.8)$ & 671 & 14.2 & 8.5 \\
\hline
\end{tabular}


を使用した。 $M_{t}$ の值と標準状態での EIの值を Table 7 に示す. 現時点では, 加撚トルクの最大と標準時での曲げ剛性を用

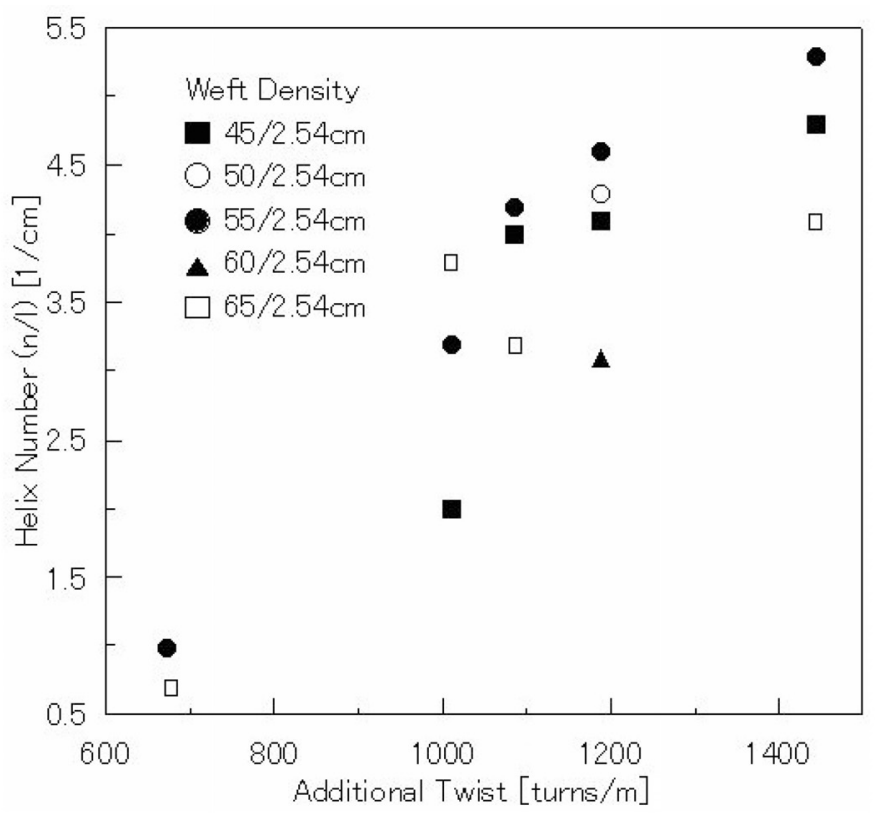

Fig. 12 Helix number of weft in cotton crepe samples (change in twist number and density of weft).

Table 6 Comparison between the predicted values and the experimental values.

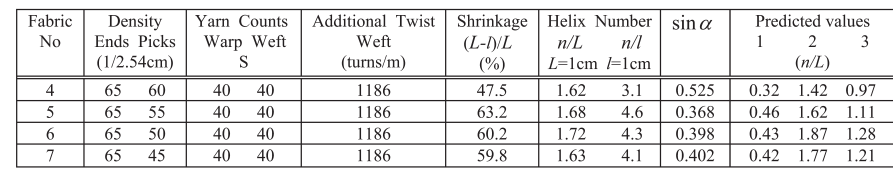

Table $7 M_{t}$ and $E I$ for yarn samples (Yarn counts 40s, Additional twist number 1186 (turns $/ \mathrm{m}$ )).

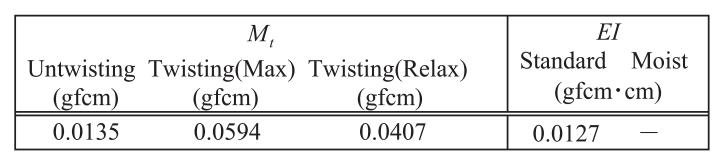

いた方が実験值に近い值となる。実際のしぼの発生は精練後 に発生するため，しぼ数の予測を行うためには湿潤時での曲 げ剛性が必要になる。しかし，精練時（湿潤時）の曲げ剛性 については測定が困難であり, 現時点では確認されていない. 今後は間接的推定法が必要と考えられる.また，クレープの シボ形状や $\sin \alpha$ にいては織物のせん断変形による拘束やた て糸の影響も考慮する必要がある.

\section{6. 結 言}

1) 強撚糸のらせん変形には曲げ剛性とねじりモーメントが 強く関与する.

2) たて糸，よこ糸に40番糸を用いた綿クレープのらせん 数は, よこ糸密度が 55 本のときに，らせん数が最大となる 傾向を示した。

3) たて糸，よこ糸に40番糸を用いた綿クレープのらせん 数は，綿糸の標準状態での曲げ剛性およびねじりモーメント (加撚時の $\max$ )により算出したしぼ数と近い值を示した.

\section{References}

[1] Yamamoto T, Takaku A (1992) Sen-i Gakkaishi, 48, 149-156

[2] Hearle JWS, Yegin AE (1972) J Text Inst, 63, 477-489

[3] Komori T, Itou M (2002) Sen-i Gakkaishi, 58, T176-T181

[4] Ishikura H, Kase S, Nakajima M (1991) J Text Mach Soc Japan, 44, T260-T267

[5] Ishikura H, Kase S, Nakajima M (1992) J Text Mach Soc Japan, 45, T65-T70

[6] Ishikura H, Yang L, Kase S, Nakajima M (1992) J Text Mach Soc Japan, 45, T154-T164

[7] Love AEH, (1944) "A Treatise on the Mathematical Theory of Elasticity $4^{\text {th }}$ Ed", Dover

[8] Yamashita S, Takatera M, Shinohara A (1997) J Text Mach Soc Japan, 50, T155-T163 